\title{
ON THE POLISH ROOTS OF THE ANALYTIC PHILOSOPHY OF RELIGION
}

\author{
ROGER POUIVET
}

University of Nancy

\begin{abstract}
Philosophers of religion of the Cracow Circle (1934-1944) are the principal precursors of what is now called the analytic philosophy of religion. The widespread claim that the analytic philosophy of religion was from the beginning an Anglo-American affair is an ill-informed one. It is demonstrable that the enterprise, although not the label "analytic philosophy of religion," appeared in Poland in the 1930's. Józef Bocheński's post-war work is a development of the Cracow Circle's pre-war work in the analytic philosophy of religion, or at least of important elements of that earlier work. Bocheński's approach in his Logic of Religion is quite original and might still be profitably studied and discussed by philosophers of religion of the analytic persuasion.
\end{abstract}

My ambition here is to present the philosophers of religion of the Cracow Circle as the principal precursors of what is now called the analytic philosophy of religion and to show that the work of these earlier philosophers was further developed by Polish philosophers in an original way into the 1970's, drawing little inspiration from the Anglo-American trend that began in the 1950's. I am struck by the ignorance of this work that is displayed in much of the contemporary literature that purports to examine the history of this philosophical genre. ${ }^{1}$ My impression is that

${ }^{1}$ For example: William Hasker, "Analytic Philosophy of Religion" in W. J. Wainwright, ed., The Oxford Handbook of Philosophy of Religion, (Oxford: Oxford University Press, 2005); Andrew Chignell and Andrew Dole, “The Ethics of Religious Belief: A Recent History" in Andrew Chignell and Andrew Dole, eds., God and the Ethics of Belief, New Essays in Philosophy of Religion, (Cambridge: Cambridge University Press, 2005); Nicholas Wolterstorff, "How Philosophical Theology Became Possible within the Analytic Tradition of Philosophy" in O. D. Crisp \& M. C. Rea, eds., Analytic Theology, New Essays in the Philosophy of Theology, (Oxford: Oxford University Press, 2009). 
contemporary authors typically start with the ill-informed conviction that the analytic philosophy of religion was from the beginning an Anglo-American affair. But in fact it is demonstrable that the enterprise, although not the label "analytic philosophy of religion," appeared in Poland in the 1930's.

Of course, one could say that philosophy of religion done in a recognizably analytic style began with Duns Scotus, Aquinas, and Anselm - and why not Aristotle? But to say that the analytic philosophy of religion began with such thinkers would simply be to use the label "analytic philosophy" not to denote an historical trend in the recent history of philosophy - the standard usage-but to refer to a way of philosophizing that pre-dates the work in logic and the philosophy of language of figures like Frege, Moore, Russell, and Wittgenstein that informed analytic philosophy as we speak of it today. I will use the term "analytic philosophy" in the ordinary way, as a label for the "logicolinguistic" style of philosophy that so powerfully exerted itself (especially in the English-speaking world, but also in Austria and elsewhere) after Frege, and, using the term in that way, will maintain that it was in the 1930's that the analytic philosophy of religion first appeared: not later, in the 1950's, and not in the English-speaking countries but in Poland, even if today's analytic philosophers of religion are not generally aware of this and often present another narrative. This will occupy the first, historical part of this paper.

In the second part of the paper, I will outline and discuss Józef Bocheński's Logic of Religion, a book that was published in English in 1965. I will present Bocheński's work as a post-war development of the Cracow Circle's pre-war work in the analytic philosophy of religion, or at least of important elements of that earlier work. This part of the paper is more of an analysis than a history. Viewed from the standpoint of Anglo-American analytic philosophy of religion as that has developed, Bocheński's approach in the Logic of Religion is quite original and might still (after 45 years) be profitably studied and discussed by philosophers of religion of the analytic persuasion. At least, it is my hope to show that it could. 


\section{THE PHILOSOPHERS OF THE CRACOW CIRCLE AS PRECURSORS OF THE ANALYTIC PHILOSOPHY OF RELIGION}

\section{Precursors of Analytic Philosophy}

The French philosopher and historian of science, Georges Canguilhem, wrote some famous pages (famous at least within the French philosophy curriculum) against the notion of a precursor. ${ }^{2}$ For him, the history of science would lose its sense by taking seriously the notion of a precursorsomeone advancing in a certain direction without arriving at the final point, with someone else, later, continuing on in the same direction and aiming at the same goal. The precursor would be "a thinker of many times," someone "extracted from his cultural frame," Canguilhem maintains: ${ }^{3}$ a fiction if not an absurdity. Let us suppose that this claim is correct about the history of science; I wonder if it would also be correct about the history of philosophy. Philosophical conceptions may be viewed as realizations of diverse theoretical possibilities within the total framework of philosophy, and not only as historical events. Sometimes a given theoretical perspective is dominant at one moment, while at another moment it is no longer taken seriously. It can even appear to have run its course and died permanently. On that account of philosophy, a so-called "precursor" is someone who does not belong to the dominant philosophical paradigm of his own epoch, but who, in retrospect, seems to have begun to mine a theoretical possibility currently dominant.

With the advent of analytic philosophy appeared the possibility of exploring the traditional philosophical problems of religion from an analytic perspective. But in what did, and does that perspective consist? The question of defining analytic philosophy is, to be sure, an international sport in which many compete. Here is my own proposal, not very original, that differentiates analytic philosophy from the socalled "Continental tradition."

${ }^{2}$ Georges Canguilhem, Études d'histoire et de philosophie des sciences, (Paris : Vrin, 1994), Introduction.

${ }^{3}$ Ibid., p. 21. 
Analytic philosophy favors:

1. Argumentation

2. A direct treatment of problems

3. Clarity, precision, and specificity

4. Literality

5. An alethic project in philosophy.

Continental philosophy favors:

A. "Visions"

B. An oblique and historical treatment of problems

C. Depth, breadth, and global perspectives

D. Metaphor and stylistic flourishes

E. An interpretative project in philosophy.

While favoring the analytic style in my own work, I make no judgments here; I am not saying that 1-5 are good and A-E bad. These are differences of objectives and ambitions. It is of course possible to make evaluative judgments concerning these various points of contrast, but one does not have to go so far as to say, for example, that literality is good and metaphor bad, or the reverse, or even that the kind of clarity given by logical analysis is a panacea in philosophy, or that depth is an obvious requirement. What matters here is rather the recognition that the objectives and ambitions are not the same on the two sides, even if there is some overlap and some neutral territory.

What is specifically important for my discussion in this section is just that analytic philosophy, from its very beginning, presented the possibility of a philosophy of religion incorporating the objectives and ambitions of the analytic approach. ${ }^{4}$ Histories of the analytic philosophy of religion generally claim that this possibility began to be exploited only in 1955, when Anthony Flew and Alasdair MacIntyre edited New Essays in Philosophical Theology. ${ }^{5}$ The implication is that the analytic philosophy of religion is an essentially Anglo-American development. If we consider analytic philosophy in general, it is obvious that no claim of a narrowly

\footnotetext{
${ }^{4}$ This possibility was already manifest in $₫ 53$ of Frege’s Foundations of Arithmetic.

${ }^{5}$ Anthony Flew \& Alisdair MacIntyre, eds., New Essays in Philosophical Theology, (London: SCM Press), 1955.
} 
Anglo-American pedigree can be taken seriously, for analytic philosophy is in no small part a Central European affair (German, Austrian, Polish, Czechoslovakian), as many historical works show clearly. ${ }^{6}$ And as for the analytic philosophy of religion, its correctly named precursors were Jan Salamucha, ${ }^{7}$ Jan Drewnowski, ${ }^{8}$ Bolesław Sobociński, ${ }^{9}$ and Józef Bocheński, all members of the "Cracow Circle"; ${ }^{10}$ so it is historically false that its roots are Anglo-American.

Of course, the historical events at the end of the 1930's in Poland were very unfavorable for the further development of this Polish analytic philosophy of religion and of philosophy in general. Jan Salamucha died heroically during the Warsaw uprising (1944); Father Bocheński fought with Polish troops against the Germans, especially in Italy (Monte Cassino). After the war, Bocheński lived in Switzerland at the Dominican monastery of Fribourg (Albertinum), and taught philosophy (and

${ }^{6}$ See Michael Dummett, Origins of Analytical Philosophy, (Cambridge, Mass: Harvard University Press, 1993). See also works by Peter Simons, Barry Smith, Kevin Mulligan, and, in French, by Jacques Bouveresse and Jean-Pierre Cometti, on the importance of Austrian (and Polish) philosophy in the development of analytic philosophy.

${ }^{7}$ Jan Salamucha, Wiedza $i$ wiara, Wybrane pisma filozoficzne, Pod redakcja J. Jadackiego i K. Swiętorzeckiej, (Lublin: Towarzystwo Naukowe Katolickiego Universytetu Lubelskiego, 1997); Knowledge and Faith, ed. by K. Swiętorzecka \& J. Jadacki, (Amsterdam: Rodopi, 2003). See R. Pouivet, "Faith, Reason, and Logic" in T. L. Smith, ed., Faith and Reason, (South Bend: St Augustine's Press, 2001); and R. Pouivet, "Jan Salamucha's Analytic Thomism" in S. Lapointe, J. Woleński, M. Marion, \& W. Miśkiewicz, The Golden Age of Polish Philosophy, (Dordrecht: Springer, 2009).

${ }^{8}$ Jan Franciszek Drewnowski, Filozofia i precyzja, (Lublin: Towarzystwo Naukowe Katolickiego Universytetu Lubelskiego, 1996). (A former student of Kotarbiński.)

${ }^{9}$ Sobociński was a professional logician. He was Leśniewski’s assistant, but he never published anything on the topic.

${ }^{10}$ Bocheński's paper, “The Cracow Circle”, in K. Szaniawski, ed., The Vienna Circle and the Lvov-Warsaw School, (Dordrecht: Kluwer, 1989) provides historical information. One can also recommend a web site dedicated to the Cracow Circle: <http://segr-did2. fmag.unict.it/ polphil/PolPhil/Cracow/Cracow.html>. In Entre la logique et la foi, Entretiens avec J. M. Bocheński (collected by J. Parys, tr. E. Morin-Aguilar), Bocheński claims that the members of the Cracow Circle were attacked (especially Salamucha) by the Polish Church, because they wanted to use the new logical instruments to discuss ancient scholastic arguments. "What would Saint Thomas have done today? He would have used mathematical logic, because it is the best, but that was exactly what the relics of ancient times rejected" (p. 22). Bocheński also refers to Father Clark in America and Father Bendiek in Germany, who also tried to use the new logical instruments to examine theological arguments. But they were completely isolated, he says. 
Soviet studies) at the University of Fribourg, though he also sojourned frequently in the United States, especially at Notre Dame University. ${ }^{11}$

\section{The Medieval Model}

Two main commitments were fundamental to the Cracow Circle. The first of these was that the logical tools introduced into philosophy by Frege, Russell, and the Lvov-Warsaw School (Jan Łukasiewicz, Alfred Tarski, Tadeusz Kotarbiński) ${ }^{12}$ are the best instruments to apply to the study of traditional problems about God, especially in the analysis and assessment of the proofs of His existence. The second was the conviction that the traditional questions of metaphysics, natural theology, and philosophical theology are not meaningless-contrary to what was suggested by logical positivists of the Vienna Circle. ${ }^{13}$ These two elements anticipated analytic philosophy of religion as it has developed from the 1950's to the present.

Thus, for example, Plantinga proposed a new analysis of Anselm's ontological argument in terms of modal logic (by using the S5 system). ${ }^{14}$ The Cracow Circle had the same sort of ambition: to examine and, eventually, to improve ancient arguments by using new logical methods. The logical instruments that were applied underwent a certain amount of evolution between the 1930's and the 1970's, but the project is essentially the same. The opposition of Polish philosophers to the positivist critique of metaphysics as meaningless ${ }^{15}$ also anticipates the renaissance of metaphysics in analytic philosophy (Alvin Plantinga, David Lewis, David Armstrong, Peter van Inwagen, etc.) and what may be called its "pre-Kantian attitude."

Two historical remarks may help here to better appreciate the Cracow Circle's project and to show how the Cracow Circle philosophers anticipated the later analytic philosophy of religion.

${ }^{11}$ Józef Bocheński, Wspomnienia, (Komorow: Wydawnictwo Antyk, 1994).

${ }^{12}$ Jan Woleński, Logic and Philosophy in the Lvov-Warsaw School, (Dordrecht: Kluwer, 1989); Roger Pouivet \& Manuel Rebuschi, eds., La philosophie en Pologne 1918-1939, (Paris: Vrin, 2006).

${ }^{13}$ See Klemens Szaniawski, ed., The Vienna Circle and the Lvov-Warsaw School, (Dordrecht: Kluwer, 1989).

${ }^{14}$ Alvin Plantinga, The Nature of Necessity, (Oxford: Clarendon Press, 1974), chap. X.

${ }^{15}$ See M. Przelecki, “The Approach to Metaphysics in the Lvov-Warsaw School” in K. Szanawski, ed., The Vienna Circle and the Lvov-Warsaw School, (Dordrecht: Kluwer, 1989). 
1. Salamucha, who worked in part within the lineage of the medieval scholar Konstanty Michalski (a specialist of 14th-century nominalism), ${ }^{16}$ and Bocheński, whose academic field was the history of logic, ${ }^{17}$ thought that Scholastic philosophy provided a rationalistic model that was to be emulated in dealing with metaphysical problems. The Scholastic model focused on arguments and examined them through public, dialectical procedures. In other words, the model of philosophy is not that of the great modern systems (Descartes' Meditations or Spinoza's Ethics); nor is it that of the broad interpretative systems of German idealism (Fichte, Schelling and Hegel) or the project of a global hermeneutics (as in Nietzsche and Heidegger). The model is rather constituted by the logical and technical discussions that we find in the works of Aquinas, Duns Scotus and Ockham, and also in some less well-known philosophers and logicians of the Medieval period.

One could complain that Michalski and Bocheński somewhat misrepresented Medieval Philosophy, which cannot be completely identified with the dialectical (or logical) period of the 13th and 14th centuries. But what is important to understanding their project is that they viewed a particular dialectical moment in the history of philosophy, rearticulated in terms of new (Fregean and Russellian) logical instruments, as constituting a methodological model that informed the philosophy of religion of the Cracow Circle. And it is this same model of philosophy that has now generally been taken up by analytic philosophers of religion. It would not be an exaggeration to speak of a renewal of Scholasticism, which must however be clearly distinguished from Neo-scholasticism.

"Neo-scholasticism" is a broad appellation that covers different trends. Its overarching project was to restore fundamental doctrines of Catholic thought. Neo-scholasticism has, alas, sometimes amounted to the pious and dogmatic rehearsal of the views of Aquinas, or, more properly, of the "Neo-scholastic Aquinas": an ecclesial creation of the end of the 19th century. What was intellectually alive and searching in Aquinas, and what was an argumentative discourse between Aquinas and other philosophers, both from earlier times and from his own time,

${ }^{16}$ See Claude Pannacio, "Konstanty Michalski on Late Medieval Nominalism" in S. Lapointe, J. Woleński, M. Marion, \& W. Miśkiewicz, The Golden Age of Polish Philosophy.

${ }^{17}$ His book in German, Formale Logik, was translated into English in 1961: A History of Formal Logic, (South Bend: Notre Dame University Press). 
was transformed by Neo-scholasticism into an ideological system, the goal of which was to oppose Catholic thought to modern philosophy and to construct a refuge for believers against what was considered to be modern errors coming from the Enlightenment.

2. Salamucha and Bocheński adopted a deliberately non-Neoscholastic attitude toward Medieval philosophy. As we noted, the Cracow Circle aimed to reconstruct Medieval arguments, especially proofs of the existence of God, using new logical tools, thereby to improve them, so that these arguments could be scrutinized philosophically in their best versions. The Cracow philosophers also wanted to renew discussion of certain basic concepts in metaphysics, for example the concepts of essence, abstraction, and the transcendental, by using the technical means provided by the new philosophy of logic. Thus, both the Cracow Circle and the current analytic philosophy of religion find inspiration in a reconstructed history of Medieval philosophy. In both cases, it is through a reparsing into our own philosophical idiom that historical philosophical theories are understood. This approach rejects what we may call an "archeological attitude" and is meant to deliver us from anachronism. ${ }^{18}$

Such are the reasons why it seems to me historically correct to claim that the analytic philosophy of religion began in Poland in the 1930's, at a time when British and American analytic philosophers had not yet embarked upon any such project. One reason why Polish philosophers could pursue this project is that Polish "scientific" philosophers in general, and the Cracow Circle philosophers in particular, never suffered from the "principle of verification" syndrome or from any form of doctrinal empiricism. The idea that "scientific" thinking in philosophy requires one to adopt an empirical or naturalistic criterion of meaning was quite foreign to the Lvov-Warsaw school of philosophy.

\section{The Principle of Verification and the Critique of "Onomatoids"}

To explain this point, I think it useful to refer to Kotarbiński’s very strong critique of "onomatoids" (apparent-terms or pseudo-terms). ${ }^{19}$ These are

${ }^{18}$ See Roger Pouivet, Philosophie contemporaine, (Paris: Presses Universitaires de France, 2008), chap. II.

19 See Tadeusz Kotarbiński, Gnosiology, The Scientific Approach to the Theory of Knowledge, Oxford: Pergamon Press, 1966. This is the translation by O. Wojtasiewicz of the second edition of Elementy teorii poznania, logiki formalnej $i$ metodologii nauk 
terms that appear to be concrete when in fact they are not. Not only "the golden mountain," "the present King of France," and "Madame Bovary's grand-mother," but also "the Unconscious," "the invisible hand," and "deconstruction," are all onomatoids. Kotarbiński’s so-called "reism" 20 posits that terms such as "smoothness" and "relationship," along with all names of properties or events, are onomatoids. The doctrine of onomatoids is, I think, part of an ethics of intellectual belief that is meant to make us aware of the risk, especially in the teaching of humanistic disciplines, of pseudo-terms. ${ }^{21}$ But note that Kotarbiński does not use this doctrine against metaphysics, and, especially, he does not say that "God" is an onomatoid. If God is a concrete entity, "God" is not at all a pseudo-term.

The principle of verification seemed to mandate the elimination of theology and all serious religious discourse. At best, such discourse is construed as fictional or poetic. But the critique of onomatoids does not have this consequence. This is the reason why an analytic philosophy of religion was possible already in the 1930's, in a country where the notion of "onomatoids" was in use. But logical positivism, and the form of naturalism that replaced it, for example in Quine's philosophy, made matters more difficult in the English-speaking countries (where positivism was not really native but derived from the Vienna Circle and its followers). Of course, verificationism did not survive for very long. But it had strong consequences for the analytic mode of philosophizing even after it had been severely criticized and generally abandoned.

Unburdened by the principle of verification, the Cracow Circle philosophers had the space needed to become the genuine precursors of the analytic philosophy of religion. Later on, English-speaking analytic philosophers of religion followed the path of Polish philosophers of whose work they were unaware. This is why I find strong reason to question the narrative according to which the philosophy of religion came late into

(1929), an obligatory reading for the students of the University of Warsaw during the thirties. See also Peter Geach, "Names in Kotarbiński's Elementy" in J. Wolenski, ed., Kotarbinski: Logic, Semantics, and Ontology, (Dordrecht: Kluwer, 1990).

${ }^{20}$ Jan Woleński, "Reism", The Stanford Encyclopedia of Philosophy (Summer 2004 Edition), Edward N. Zalta (ed.), <http://plato.stanford.edu/entries/reism/>.

${ }^{21}$ See Roger Pouivet, "Kotarbiński et l'éthique intellectuelle", in R. Pouivet \& M. Rebuschi, eds., La philosophie en Pologne 1918-1939 (Paris: J. Vrin, 2006). 
the analytic movement, in the 1950's to be more precise. For what has since been called "Analytic Thomism" had already been introduced by Salamucha and Bocheński, before the Second World War; ${ }^{22}$ and it seems to me that this amounted to an initiation of the whole program that we now call the "analytic philosophy of religion."

What happened in Polish philosophy after the Second World War? We find Marxist-inspired works, epistemology and philosophy of science (or what Polish philosophers of the so-called "Poznan School" called "Methodology"), logical works (very technical even if quite inventive, for example the works of Roman Suszko; though such works were often detached from philosophical concerns), social and political philosophy, and the phenomenological school that Roman Ingarden initiated in Cracow. ${ }^{23}$ The philosophy of religion was pursued in Catholic universities, though mainly in Lublin ${ }^{24}$, with figures like Karol Wojtyła, the future John-Paul II. This was largely neo-scholastic philosophy, with influences from French philosophers like Etienne Gilson, Jacques Maritain, Jean Nabert, Maurice Nédoncelle, and from the phenomenology inspired by Max Scheler; and its practitioners were more interested in "existentialism" than in analytic philosophy.

And Bocheński? At the University of Friburg, in Switzerland, he created a department of Soviet studies and was one of the leading specialists of Communist thought, even acting as a consultant for Western governments in "Kremlinology." But he also defended, in numerous books, a conception of philosophy inspired by the methodological ideals of the Lvov-Warsaw school. While Bocheński is better known for his

${ }^{22}$ For the notion of "Analytic Thomism", see John Haldane, "Analytical Thomism: A Brief Introduction", Monist, October 1997, vol. 80, Nr 4 (Analytical Thomism); see also Roger Pouivet, "Le thomisme analytique, à Cracovie et ailleurs", Revue Internationale de Philosophique, $\mathrm{n}^{\circ} 3 / 2003$ (Philosophie analytique de la religion).

${ }^{23}$ See Zbigniew A. Jordan, Philosophy and Ideology: The Development of Philosophy and Marxism-Leninism in Poland since the Second World War, (Dordrecht: Reidel, 1963).

${ }^{24}$ See Mieczyslaw Krąpiec, Andrzej Maryniaczyk, The Lublin Philosophical School, (Lublin: Polskie Towarzystwo Tomasza z Akwina, Katedra Metafizyki KUL, 2010). In the Lublin School, Jerzy Kalinowski is an interesting figure. From Lublin, he emigrated to France at the end of the 1950's, and developed there-in the "golden age" of French Marxism and Structuralism-deontological logic and Thomistic metaphysics. See Jerzy Kalinowski, L'impossible métaphysique, (Paris: Beauchesne, 1981); Michel Bastit \& Roger Pouivet, eds., Jerzy Kalinowski: Logique et Normativité, Philosophia Scientiae, vol. 10, cahier, 2006. 
works in the history of logic, especially the logic of antiquity and the Middle Ages, he also wrote a Logic of Religion published in 1965, based upon lectures given at New York University in 1963. My question is: How is it possible for such a book to be published in the United States at that date, in English, and then to be virtually ignored by analytic philosophers of religion? ${ }^{25}$ Anthony Kenny edited Salamucha's paper on the formalization of Aquinas's proof ex motu in Aquinas, A Collection of Critical Essays. ${ }^{26}$ But, in general, the Polish roots of the analytic philosophy of religion, and its further development by Bocheński, have simply been ignored. Could it be that the narratives of the history of the analytic philosophy of religion suffer from parochialism?

\section{THE JUSTIFICATION OF RELIGIOUS DISCOURSE IN BOCHEŃSKI'S LOGIC OF RELIGION}

\section{The Analysis of Religious Discourse}

Having reviewed the relevant history of the Cracow Circle and mentioned the decline, and inchoate resurrection, of Polish analytic philosophy of religion in the wake of the Second World War, I now turn to a somewhat more detailed account and analysis of Józef Bocheński's justification of religious discourse, as presented in his Logic of Religion. This will provide the reader with a better idea of the kind of work that derived, in the post-war period, from the Cracow Circle's pre-war program concerning religious belief.

It is clear that the Logic of Religion may be understood in part as a development of the thinking of the Cracow Circle, although the case must not be overstated, and it is difficult to say to what extent Bocheński himself thought of it in that way. One reason is that he includes neither quotations nor references in the book, and so no explicit connection is made to Salamucha or other members of the Cracow Circle although the influences may be justly inferred. The reason given by Bocheński for this

${ }^{25}$ The book was reviewed in the Philosophical Review vol. 76, Nr 4, 1967; but beyond that, it was hardly noticed by those writing in the field.

${ }^{26}$ A. Kenny, Aquinas : A Collection of Critical Essays, (South Bend: Notre Dame University Press, 1976). 
omission of references is that The Logic of Religion is a "purely speculative book." 27 But many purely speculative books contain quotations and references. By "speculative," Bocheński seems to mean that his account is a priori: not historical, empirical, or hermeneutical. This gives to the book a very special rhetorical aspect that is characteristic of the Lvov-Warsaw school, ${ }^{28}$ and in itself constitutes a good reason for thinking that the book continues the Cracow Circle's program in philosophy of religion.

The book could also be said not to be about religion, but about religious discourse. And it is surely one of the main methodological aspects of the Lvov-Warsaw school and (consequently) of the Cracow circle, that the analysis of language is considered the proper medium by which to approach many domains in philosophy. We may note that Bocheński is a realist (as were the Polish philosophers of the LvovWarsaw school generally). He says, "when a logician states that, if no $\mathrm{A}$ is $\mathrm{B}$, then no $\mathrm{B}$ is $\mathrm{A}$, he is not talking about the rules of reasoning but, at least primarily, he is establishing a necessary connection between two states of things." 29 Thus, to be about religious discourse is not to be about discourse alone. Even less is it to suggest that religious matters are simply linguistic matters, or that religion is a language game with no matters of fact or realities to be considered.

Bocheński endeavors, first, to prove that general logic can be applied to religious discourse (Chapter II, "Religion and Logic"); secondly, to describe the formal structure of religious discourse and the logical relations between religious and profane discourses (Chapter III, "The Structure of Religious Discourse"); and thirdly, to discuss certain fundamental problems concerning the meaning and justification of religious discourse (Chapter IV, "Meaning in Religious Discourse," and Chapter V, "Justification of Religious Discourse.") ${ }^{30}$ I will here briefly discuss the part of the book that concerns the justification of religious discourse. The reason is that a central part of the analytic philosophy

\footnotetext{
${ }^{27}$ Joseph M. Bochenski, The Logic of Religion, (New York: New York University Press, 1965), p. VII.

${ }^{28}$ Today, the followers of the Lvov-Warsaw school still employ this rhetoric (perhaps one could even say aesthethics) of axiomatics in philosophy.

${ }^{29}$ J. M. Bochenski, The Logic of Religion, p. 4.

${ }^{30}$ This the way the program of the book is described by W. Rowe in his review of the book (Philosophical Review, vol. 76, Nr 4, 1967).
} 
of religion has been devoted, at least until recently, to this problem of justification. It is thus especially interesting to compare Bocheński's account with what contemporary writers call the "epistemology of religious beliefs."

\section{The Question of Justification}

What Bocheński proposes are distinctions which, in the end, yield a classification of the different theories of justification. Justification can be direct or indirect. In the former case, justification is "an act of (sensuous or non sensuous) insight; the object must always be present." ${ }^{1}$ If the justification is indirect, "it consists of a reasoning; the object is not present." ${ }^{\prime 2}$ Indirect justification is deductive or reductive; and here Bocheński borrows a distinction from Łukasiewicz (and Jevons, according to Eukasiewicz). Here is Bocheński's explanation of the distinction:

Every reasoning has as one premise a conditional, or a sentence which can be easily transformed into a conditional. As the premise we use, in deduction, a sentence of the same shape as the antecedent of that conditional and obtain as conclusion a sentence of the shape of its consequent. In reduction we have as a second premise a sentence of the shape of the consequent, and we obtain as conclusion a sentence of the shape of the antecedent of the first premise. $^{33}$

This means that the reductive reasoning can be either inductive or abductive.

If the premises are taken from basic dogma, the question becomes that of knowing how the dogma is itself justified. The basic dogma is "a meta-logical rule, according to which every element of objective faith... has to be accepted as true." ${ }^{34}$ Then, two questions may be asked:

(A) Is it possible to justify the basic dogma?

(B) And if it is, what is the difference between a justification in the religious discourse and in the profane discourse?

\footnotetext{
${ }^{31}$ J. M. Bochenski, The Logic of Religion, p. 118.

${ }^{32}$ Ibid.

${ }^{33}$ Ibid., p. 120.

${ }^{34}$ Ibid., p. 61.
} 
These problems are considered by Bocheński to be "problems of applied logic, and therefore ... we are trying to carry out logical analysis of a material which is empirically given." ${ }^{35}$ Logic is here applied to a certain extra-logical field. But this can be done in two different ways. (1) One can add some extra-logical terms, axioms and rules to certain portions of formal logic. "In this sense, for example, contemporary physics or any sort of theology is applied logic," ${ }^{36}$ Bocheński says. (2) But in the "proper use of the term . . . we may mean by 'applied logic' the study of those logical laws and rules ... which are used in a given field." ${ }^{37}$ Very often, such special parts of logic must be developed ad hoc, according to the use that is made of them in the field in question. ${ }^{38}$ Bocheński defines a theorem:

For all $\mathrm{f}$ : if $\mathrm{f}$ is a field of human activity, then there is applied logic of $\mathrm{f}$ if and only if $f$ includes discourse which embodies or expresses some objective structures. ${ }^{39}$

It seems to me that what we would today call the "epistemology of religious beliefs" is what Bocheński considers to be the applied logic of religious discourse. Logic has historically been developed for the sake of science and therefore limited to propositions, whether logical or factual. But that limitation is not a necessity. For example, during the 20th century, a formal logic of morals was developed in which most formulae represent not indicative sentences but imperative ones. And performative sentences have also been shown to be appropriate objects of formal logical study. Logic cannot be applied "where there is no discourse at all" or "where discourse is present, but does not embody or express an objective structure." 40 This is the case if a discourse is completely meaningless or if it expresses only subjective states (although even in this

${ }^{35}$ Ibid., p. 125.

${ }^{36}$ Ibid., p. 6.

${ }^{37}$ Ibid.

${ }^{38}$ I think that this difference is important: a large part of what has been done in logical studies under the name of "non classical logic" is in fact what Bocheński calls "applied logic", i.e. an ad hoc logic made to formalize the way we reason in a given field rather than a formal logic independent of any given field.

${ }^{39}$ J. M. Bochenski, The Logic of Religion, p. 7.

${ }^{40}$ Ibid., p. 8. 
last case a semantics is possible, but this semantics cannot be formal). And it is also only if a discourse expresses not only objective structures but propositions that a methodology is possible, "for methodology is essentially a theory of truth-conditions, and only propositions are true." 41

\section{An Epistemological Inquiry}

According to Bocheński, the condition for framing an "applied logic" (and thus an epistemology of religious belief, if I am right in thinking that these are the same) is a propositional account of religious belief. A negative answer to the question whether it is possible to justify basic dogma (question (A), above) seems to entail a non-propositional account of religious belief, because it forbids the application of logic to religious discourse. In connection with the justification of basic dogma, Bocheński speaks about "the blind-leap theory," that is, a theory of justification of religious discourse that describes faith as belief in virtue of absurdity: Credo quia absurdum, as Tertullian said. I suppose that Bocheński has in mind something like Kierkegaard's account. At any rate, the notion of a "blind leap" seems to be Kierkegaardian. This non-propositional account of religious belief is also akin to Wittgenstein's theory of religious discourse in the Tractatus Logico-Philosophicus, and even more to the account of religious commitment given in his lectures on religious belief. Bocheński is quite critical of the blind-leap theory. For him, vast parts of religious discourse are not intended to be understood as propositional, but "some parts of the religious discourse of every religion are intended by their users to express and assert propositions." ${ }^{32}$ This means that Bocheński rejects a purely phenomenological account of religious belief. If belief were completely indifferent to the truth of propositions composing the Creed, for example, that would constitute a deep modification of the nature of religious belief as traditionally understood. It seems to me that it would mean, above all, that religious "belief" would consist only in a certain sort of experience and an attitude of faith without any propositional content. In that case, religion would lie beyond the limits of logic and of epistemology.

\footnotetext{
${ }^{41}$ Ibid.

${ }^{42}$ Ibid., p. 41.
} 
On the other hand, for Bocheński, if there is positive answer to the question (A), then that answer may be either "complete" or "incomplete." ${ }^{3}$ "Complete" does not mean that the believer purports to have full certainty, "comparable with that of direct insight or of convincing deductive proof." It means rather that the acceptance of the basic dogma is determined solely and entirely by a rational justification. "Incomplete" means that the act of faith is decisive. And by faith, one means something (a) distinct from science (there is no "proof"), (b) free (there is no compelling reason to accept it) and freely chosen (a matter of will), and (c) certain (but in a different way from that which is scientifically certain). "Faith is said to be produced by the human will with the help of divine grace, or by illumination by Buddha, and so on," ${ }^{45}$ Bocheński says.

Thus, a theory of complete (if not deductive or intuitively direct) justification of religious discourse is a rationalistic theory. The premises used in such a case can be factual (strictly rationalistic theory) or can be sentences expressing accepted moral and esthetic propositions (broadly rationalistic theory). The first case corresponds, it seems to me, to natural theology, and the second case corresponds to moral arguments within the epistemology of religious belief. Bocheński himself rejects a strictly rationalistic theory: religious discourse and profane discourse would thereby be confused. According to him, logic of religion seems to show that the project of natural theology, except perhaps as a part of a justificatory process ${ }^{46}$ is an impossible one. But more broadly, the project of a complete justification is criticized. The (free) act of faith seems to be indispensable.

An incomplete justification can be direct or indirect. Bocheński does not say a lot about the difference. He seems to mean that a direct justification is not built upon deductive or reductive reasoning. Two

${ }^{43}$ Ibid., p. 127.

${ }^{44}$ Ibid., p. 131.

${ }^{45}$ Ibid., p. 135. In this sense, the Logic of Religion is not so far from what Cardinal Newman called a Grammar of Assent, even if Newman's project stresses the psychological aspects (at least in the sense of a philosophical psychology) of this justificatory process, and Bocheński's its logical aspects. For a recent account that deals historically and theoretically with similar questions (the relation between the motives of credibility and the act of faith), see the remarkable book by John T. Lamont, Divine Faith, (Aldershot: Ashgate, 2004).

${ }^{46}$ However, Bocheński says nothing about this possibility. 
theories of incomplete direct justification are discussed: the supernatural "insight theory" and the "trust theory." Bocheński claims that the former "has never been seriously defended and does not merit consideration," which I find strange. For the French philosopher and theologian, Arnaud, so influenced by Augustine (and Descartes), says in the Logique de PortRoyal: "Just as no other marks are needed to distinguish light from darkness except the light itself which makes itself sensed sufficiently, so no marks are necessary to recognize the truth but the very brightness which surrounds it and to which the mind submits, persuading it in spite of itself." ${ }^{47}$ One might also say that, in a sense, Plantinga's Calvinistinspired notion of sensus divinatis corresponds in part to the insight theory. The proper function of the sensus divinitatis and the operation of the internal instigation of the Holy Spirit are presented by Plantinga in terms of an immediate (i.e., non-inferential) awareness of the truth of theistic, and specifically Christian, belief. But Bocheński considers that insight can be used only to justify a necessary sentence, and sentences belonging to the basic dogma are not necessary. "Such sentences cannot be justified by direct insight, not even in part," 48 he maintains. If Plantinga's account corresponds even partly to what Bocheński calls the insight theory, it would mean that someone has recently defended this theory that Bocheński thought had never been defended by anyone.

In connection with the "trust theory," Bocheński criticizes the case where the basic dogma is justified by direct trust in Revealing agency, exactly as a child believes its mother when she says that there is a city called "New York." Bocheński defends what one calls today a reductionist theory of testimony, like Hume's, according to which testimony is credible only because, and to the extent that, one has independent reasons for accepting whatever testimony led to its formation. But Bocheński defends this position only in the case of religious trust. For, in religious trust, we are not exactly in the same situation as the child and its mother. "You can trust only a person whom you know to exist," ${ }^{49}$ Bocheński says, and so you need prior confirmation that God exists in order to have confidence in the truth of what He says. And you even need prior confirmation that

${ }^{47}$ Antoine Arnauld and Pierre Nicole, Logic, or the Art of Thinking, tr. and ed. J.V. Buroker, (Cambridge: Cambridge University Press, 1996), p. 8.

${ }^{48}$ J. M. Bochenski, The Logic of Religion, p. 128.

${ }^{49}$ Ibid., p. 137. 
God is speaking. The child, by contrast, knows directly of the existence of its mother and also knows that it is she who speaks. So the "trust theory" does not find strong support according to Bocheński.

An indirect theory of justification can be deductivist. "Radical" deductivism purports to establish, by deductive means, the certainty of religious discourse to a greater degree than can attach to any other knowledge. A more "moderate" deductivism "admits that there is, in religious discourse, an element that is not demonstrable: but whatever is demonstrable in religious discourse is demonstrable by deductive proof." ${ }^{0}$ The main objection by Bocheński against deductivism is "that no historical sentence can be demonstrated by deduction." ${ }^{51}$ But if one means to prove, from a proof of the existence of God, the truth of propositions contained in a Creed, then one must establish historical sentences deductively; and this is impossible, according to Bocheński.

\section{The Negative Results of Bocheński's Epistemology of Religious Belief}

Two other indirect theories of justification exist, both reductive, and thus both applying only inductive rules. Consequently, they cannot yield certainty. "As a result, what has been said above about the incompleteness of every justification of the basic dogma is confirmed," 52 says Bocheński. In one kind of reductive theory, the basic dogma is supported by authority; not the authority of the Revealing agent, however, but a human authority. Acceptance of the latter may come through insight into the person of the authority itself, as when a child accepts the word of its mother, although more often there is a reasoning process that conduces to the acceptance of such an authority. The incomplete and reductive theory is "the religious hypothesis." According to Bocheński, "This theory has been voiced many times by different theologians, mostly under misleading titles such as 'pragmatic justification." 53 The basic dogma is constructed by the believer, prior to the act of faith itself, in the form of an explanatory sentence. This is the religious hypothesis, and it serves to explain his experience. This is close to a reductive argument, and, I think, amounts to what we now

\footnotetext{
${ }^{50}$ Ibid., p. 140.

${ }^{51}$ Ibid., p. 141.

${ }^{52}$ Ibid., p. 141.

${ }^{53}$ Ibid., p. 148.
} 
call "an inference to the best explanation." But Bocheński thinks that in the case of a religious hypothesis, the experiential sentences which form the starting point of the inference have very broad content, even encompassing a person's "total experience." The difference between this and the method of hypotheses in the sciences is that sentences concerning moral and esthetic values are included. The religious hypothesis has the advantage of giving a meaning to the world and to existence, as some writers might express it, or playing "the role of an axiom out of which the remainder is thought to be deduced," 54 as Bocheński says. He also notes two "curious phenomena" concerning the religious hypothesis model: "the difficulty of persuading another man of his truth" (for we do not have the same total experience) and "the difficulty of overthrowing [such an hypothesis] by falsification" 55 (due especially to its breadth).

Finally the situation of the justification of religious discourse, and belief, seems to be logically and epistemologically bad, in Bocheński's view. We have many theories: the rationalistic theory, the trust theory, the deductivist theory, the authority theory, the theory of the religious hypothesis. But none of them seems easily defensible, or even defensible with difficulties. Ultimately, Bocheński is not prepared to say that religious discourse is logically warranted or justified. At least, the justification of religious discourse, as contrasted with justification within religious discourse, is not at all convincing. But for Bocheński what matters for the philosophy of religion (as contrasted with apologetics) is the mapping of the theories and their epistemology, and not the conclusion that religious beliefs are ultimately warranted or justified. Clearly, for Father Bocheński, they are not!

\section{CONCLUSION}

If what I said in this paper is right, then the analytic philosophy of religion is a Polish initiative. In the first place, this claim helps to rectify an image of Polish philosophy of religion as mainly a mélange of Neo-Thomism and phenomenology, as illustrated, for example, in the philosophical

\footnotetext{
${ }^{54}$ Ibid., p. 149.

${ }^{55}$ Ibid., pp. 149-50.
} 
and theological works of John Paul II. Secondly, this claim shows also that some recent papers ${ }^{56}$ present an inaccurate, or at least incomplete, narrative about the analytic philosophy of religion, and the present article may serve to correct some historical mistakes. Thirdly, just as some works in the history of analytic philosophy have had the result of happily bringing this philosophy back to Central Europe, where it was so important before the Second World War, I hope that the rediscovery of the Cracow Circle may encourage, for the analytic philosophy of religion, the same sort of return to its home ground. Finally, a re-examination and appreciation of Polish work-not least Bocheński's Logic of Religion-will show that mainstream analytic philosophy of religion has yet to meet challenges heretofore overlooked. The very systematic way Bocheński examines the possible ways of analyzing the question of the justification of religious belief shows that these are not so numerous. His method is "logical," systematic, and a priori. In the end, Bocheński's conclusion concerning the justification of religious belief is skeptical. Those who wish to claim that justification is somehow possible must show that there are possibilities that do not fall into one of Bocheński's categories, or that the distinctions he proposed were not the right ones.

\footnotetext{
${ }^{56}$ See note 1.
} 